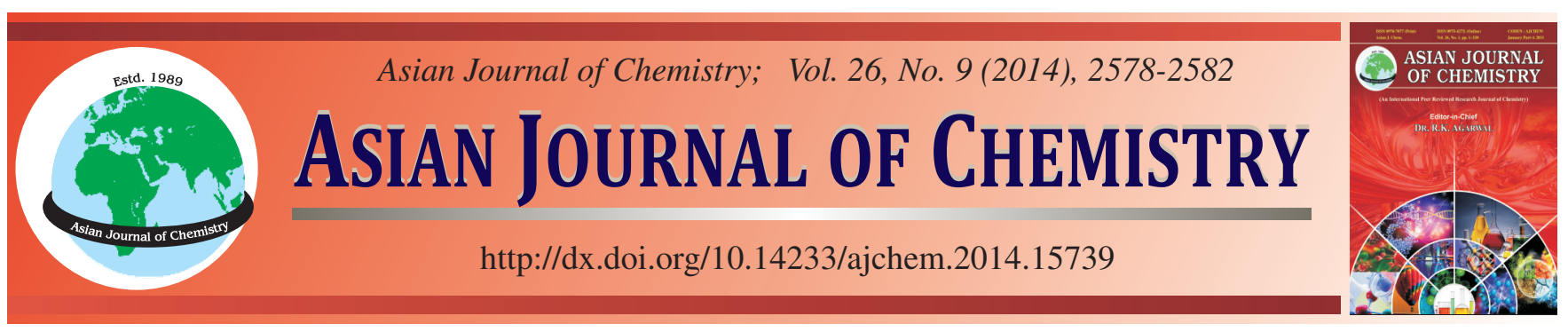

\title{
Studies on the Interaction Mechanism of Morin-Co(II) with DNA and Preparation of Electrochemical DNA Biosensor
}

\author{
Shu-Yan Niu ${ }^{*}$, Huan -Huan Cui, Xiao-Tong Shen and Ming-Liang Wu
}

Key Laboratory of Eco-chemical Engineering, Ministry of Education, College of Chemistry and Molecular Engineering, Qingdao University of Science and Technology, Qingdao 266042, P.R. China

*Corresponding author: Fax: +86 532 84022681; E-mail:wenzhangggg@ 126.com

Received: 7 May 2013;

Accepted: 2 September 2013;

Published online: 28 April 2014;

AJC-15073

\begin{abstract}
Fabrication and electrochemical characterization of a sensitive and novel DNA electrochemical biosensor for the detection of the specific target DNA fragment with a new prepared indicator was presented. The sensor was based on multi-walled carbon nanotubes functionalized with a carboxylic acid group (MWNTs- $\mathrm{COOH}$ ) as the signal hybridization detection enhancement element. The well dispersed MWNTs were dripped onto the glassy carbon electrode (GCE) surface firstly to prepare MWNTs/GCE. Oligonucleotides with the $5^{\prime}$-amino group were covalently bonded to the carboxyl group of carbon nanotubes. Cyclic voltammetry was used to characterized the modified electrode. The hybridization events were monitored by differential pulse voltammetry (DPV) analysis using a novel electroactive intercalator Morin$\mathrm{Co}(\mathrm{II})$ as an indicator. The specific coliform DNA fragment was detected by the proposed biosensor with a good linear range and a lower detection limit. The linear range is from $2 \times 10^{-9} \mathrm{M}$ to $5 \times 10^{-10} \mathrm{M}$ with a detection limit of $8.1 \times 10^{-11} \mathrm{M}(3 \sigma, \mathrm{n}=7)$. Moreover, the sensor presentes excellent stability and a high repeatability.
\end{abstract}

Keywords: DNA, Electrochemisitry, Multi-walled carbon nanotubes, Morin-Co(II).

\section{INTRODUCTION}

Over the past decades, there has been considerable interest for DNA hybridization biosensors for applications in many fields: DNA diagnostics, gene analysis, fast detection of biological warfare agents and environmental investigation ${ }^{1,2}$. The determination of the human genome, the need for detection of biological pathogens and the development of genetically modified organisms have all led to a demand for simple portable DNA detection tools, which has drawn great attention to electrochemical DNA hybridization biosensors ${ }^{3}$.

Electrochemical DNA biosensor offers great promise for many DNA hybridization applications and lends itself to mass fabrication. There are several challenges that current research aims to overcome, including higher selectivity, higher sensitivity, shorter assay times and greater simplicity in performing the assay ${ }^{4}$. DNA can be immobilized on sensor surfaces with methods similar to those used for enzyme-based biosensors i.e., adsorption, covalent immobilization and avidin (or streptavidin) biotin interaction ${ }^{5}$.

Recently, the novel surfaces modified with nano-materials have presented an excellent prospect for biological recognition surfaces in order to develop a more selective and sensitive DNA biosensor technology $y^{6}$. Carbon nanotubes (CNT), which can be categorize into multiwall (MWCNTs) and single-wall (SWCNTs) carbon nanotubes. In general, the high surface area, hollow geometry and the useful mechanical properties of CNTs combined with their electronic conductivity and ability to promote electron-transfer reactions ${ }^{7}$. The lower overvoltages and higher peak currents are observed in the voltammetric response of several molecules at electrodes modified with CNTs. Due to these unique properties, CNTs have received enormous attention for the preparation of ultrasensitive electrochemical biosensors. Besides, many other potential and practical applications of CNTs have been reported in the fields of chemical sensors ${ }^{8-9}$, biosensors ${ }^{10,11}$, cell counters ${ }^{12}$, energy storage $^{13}$, field emission materials ${ }^{14}$, catalyst supports ${ }^{15}$, highsensitivity nanobalances ${ }^{16}$, etc.

On the other hand, the hybridization indicators, which are compounds that interact in measurably different ways with ssDNA and with dsDNA, are thus developed and are often employed in the detection of DNA hybridization. The binding mechanisms between DNA and various redox substances, such as metal complexes ${ }^{17,18}$, anticancer or antivirus drugs ${ }^{19}$ and organic dyes ${ }^{20}$, have been extensively investigated. Morin hydrate (2-(2,4-dihydroxyphenyl)-3,5,7-trihydroxy-4H-1benzo-pyran-4-one), a light yellowish natural plant dye, is known to have a broad pharmacological activity, such as 
antitumour $^{21}$, antioxidation ${ }^{22}$ and possibly even protective effects against chronic diseases ${ }^{23}$. In general, compared with the ligand, the morin complex is considered to have a better biological activity due to its cooperative effectivenes. Many different methods have been used to study the interaction with DNA, in particular the electrochemical analysis ${ }^{24-25}$.

In this work, a convenient and effective strategy by using MWCNT-COOH as linker between GCEs and DNA is proposed. Firstly, MWCNT-COOH was mixed in DMF to form the suspension which was cast on a cleaned GCEs electrode surface to form MWCNT-COOH films. Subsequently, 5' ends of DNA probes with amino groups was assembled onto the MWCNT films in the present of EDC by covalent bonds interaction between carboxyl of MWCNT and 5'-amino group. Morin was chosen as ligand for the synthesis of novel cobalt complex of $\mathrm{Co}\left(\mathrm{C}_{15} \mathrm{H}_{9} \mathrm{O}_{7}\right)_{2} \cdot 3 \mathrm{H}_{2} \mathrm{O}$ (abbreviated by morin- $\mathrm{Co}$ (II) or $\mathrm{CoL}_{2}$ ). Due to the special molecular structure of morin, it was convinced that $\mathrm{CoL}_{2}$ could perform a different binding role with DNA from other common metal complexes. The interaction of synthesized Morin-Co(II) with DNA was investigated with cyclic voltammetry (CV). Using Morin-Co(II) as electroactive indicator, a novel electrochemical DNA biosensor was developed with the accomplishment of hybridization of immobilized probe DNA with its complementary singlestranded DNA (ssDNA) on glassy carbon electrode (GCE) by differential pulse voltammetry (DPV). The specific coliform DNA fragment was detected by the proposed biosensor with a good linear range and a lower detection limit.

\section{EXPERIMENTAL}

Elemental analysis was performed on Elementar Vario EL III analyzer. All electrochemical measurements, including cyclic voltammetry (CV), differential pulse voltammetry (DPV) were performed with a CHI 832 Electrochemical Analyzer (Shanghai Chenhua Instrument Company, China). A threeelectrode system was employed, including Pt wire as the auxiliary electrode, $\mathrm{Ag} / \mathrm{AgCl}$ as the reference electrode and glassy carbon electrode (GCE) as the working electrode.

Salmon sperm DNA (dsDNA) was purchased from Shanghai Huashun Biological Engineering Company $(\geq 95$ $\left.\%, \mathrm{~A}_{260} / \mathrm{A}_{280}>1.8, \varepsilon_{260}=6600 \mathrm{M}^{-1} \mathrm{~cm}^{-1}\right)$. EDC was purchased from Sigma and used without further purification. MWCNTs with a diameter of about 10-30 nm and a length of around 1$10 \mu \mathrm{m}$ were obtained from Sun Nanotech Co. Ltd. (Jiangxi, China). Three 24-base oligonucleotides were purchased from SBS Genetech Company (Beijing, China) and purified using PAGE to obtain the purity of $=95.0 \%$. The base sequences were as follows:

ssDNA probe $\left(\mathrm{S}_{1}\right)$ : 5'- $\mathrm{NH}_{2}-\mathrm{GAG}$ CGG CGC AAC ATT TCA GGT CGA-3'

Complementary target ssDNA $\left(\mathrm{S}_{2}\right): 5^{\prime}$-TCG ACC TGA AAT GTT GCG CCG CTC-3'

Three-base mismatch target ssDNA $\left(\mathrm{S}_{3}\right): 5^{\prime}$-TCG TCC TGA AAC GTT GCG CCT CTC-3'

Single mismatch target ssDNA $\left(\mathrm{S}_{4}\right)$ : 5'-TCG ACC TGA AAC GTT GCG CCG CTC-3'

non-complementary target DNA $\left(\mathrm{S}_{5}\right)$ : 5'- GAG CGG CGC AAC ATT TCA GGT CGA -3'
The italicized bases in $\mathrm{S}_{3}$ and $\mathrm{S}_{4}$ indicate those mismatched with $\mathrm{S}_{1}$

All oligonucleotide stock solutions were prepared in TE solution (10 mM Tris- $\mathrm{HCl}$ plus $1 \mathrm{mM}$ EDTA, at $\mathrm{pH}$ 8). Other chemicals employed were all of analytical grade. Ultrapure water was used throughout.

Preparation of $\mathrm{CoL}_{2}$ : The complex of $\mathrm{Co}\left(\mathrm{C}_{15} \mathrm{H}_{9} \mathrm{O}_{7}\right)_{2} \cdot 3 \mathrm{H}_{2} \mathrm{O}$ was synthesized as described in the literature ${ }^{26}$. Elemental analysis: Calcd. (Theoretical Value) for $\mathrm{Co}\left(\mathrm{C}_{15} \mathrm{H}_{9} \mathrm{O}_{7}\right)_{2} \cdot 3 \mathrm{H}_{2} \mathrm{O}$, $\%$ : C 50.74 (50.35); H 3.35(3.36). The formula of the complex was shown in Fig. 1.

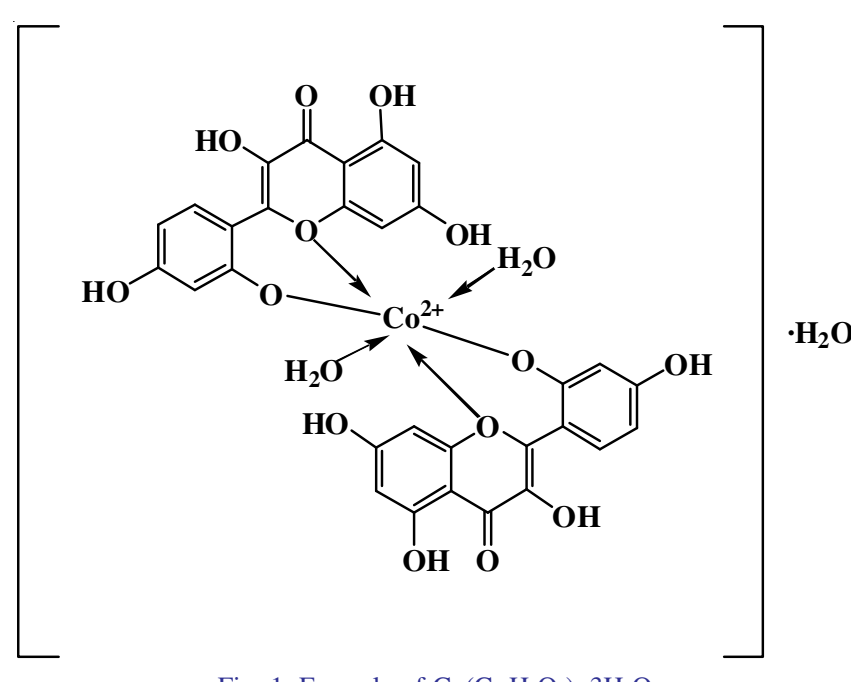

Fig. 1. Formula of $\mathrm{Co}\left(\mathrm{C}_{15} \mathrm{H}_{9} \mathrm{O}_{7}\right)_{2} \cdot 3 \mathrm{H}_{2} \mathrm{O}$

Electrochemical study on the interaction between $\mathrm{CoL}_{2}$ and dsDNA: The glassy carbon electrode(GCE) was polished successively with $1.0 \mu \mathrm{m}, 0.3 \mu \mathrm{m}$ and $0.05 \mu \mathrm{m} \alpha-\mathrm{Al}_{2} \mathrm{O}_{3}$ suspension, followed with extensively rinse in ultrapure water with sonication. Appropriate amount of dsDNA and $\mathrm{CoL}_{2}$ were mixed and incubated in 0.2 M PBS buffer ( $\mathrm{pH}$ 6.0) for $5 \mathrm{~min}$. The interaction characterization of $\mathrm{CoL}_{2}$ with DNA was performed by cyclic voltammetric method with the potential scan from $0.2 \mathrm{~V}$ to $0.8 \mathrm{~V}$ at the scan rate of $0.1 \mathrm{~V} \cdot \mathrm{s}^{-1}$.

Preparation of MWCNTs-COOH: MWCNTs functionalized with carboxylic acid groups (MWCNTs-COOH) were prepared by heating at reflux with concentrated $\mathrm{HNO}_{3}$ for approximately $10 \mathrm{~h}$. The MWCNTs-COOH suspension was prepared by dispersing one milligram MWCNTs-COOH in $10 \mathrm{~mL}$ of $\mathrm{N}, \mathrm{N}$-dimethylformamide (DMF) with the aid of ultrasonic agitation.

DNA covalently immobilized to the MWCNTs-COOH modified GCE surface: The covalent immobilization of oligonucleotides to MWCNTs-COOH on GCE was conducted as follows: $10 \mu \mathrm{L}$ of $1 \mathrm{mg} \mathrm{mL}^{-1}$ suspension of MWCNTs-COOH was dropped onto a freshly smoothed GCE surface uniformly and had the solvent evaporated under an infrared lamp. The electrode was thoroughly rinsed, first with ethanol and then with ultrapure water to remove excessive nanotubes. For oligonucleotide immobilization, the MWCNTs modified electrode was immersed in a $30 \mu \mathrm{M}$ acetate buffer ( $\mathrm{pH}$ 5.2) containing $10 \mathrm{mM}$ EDC for $1 \mathrm{~h}$. The EDC-attached electrode was washed with acetate buffer and subsequently incubated in a $3.5 \mu \mathrm{M}$ oligonucleotides/acetate buffer solution for $12 \mathrm{~h}$ at room 
temperature. In this process the probe oligonucleotides were immobilized on the GCE through the covalent amide bonds formed by the carboxyl groups on the nanotubes and the amino groups on the oligonucleotides.

Hybridization on the ssDNA-immobilized electrode: The hybridization was carried out on $\mathrm{S}_{1}$-immobilized electrode in $0.20 \mathrm{M}$ Tris- $\mathrm{HCl}$ buffer solution ( $\mathrm{pH}$ 7.0) containing complementary ssDNA segment $\left(\mathrm{S}_{2}\right)$, three-base mismatch target ssDNA $\left(\mathrm{S}_{3}\right)$, single mismatch target ssDNA $\left(\mathrm{S}_{4}\right)$ or noncomplementary ssDNA segment $\left(\mathrm{S}_{5}\right)$, respectively. The solution was stirred for $1 \mathrm{~h}$ at $37^{\circ} \mathrm{C}$ and then the electrode was dried at room temperature and rinsed with $0.20 \mathrm{M} \mathrm{B-R}$ buffer and ultrapure water successively to remove extra target ssDNA.

Intercalation of hybridization indicator: The accumulation of $\mathrm{CoL}_{2}$ on the $\mathrm{S}_{1}$-immobilized or hybridized surface was performed by immersing the electrode into 0.2 M PBS buffer (pH 6.0) containing $5.52 \times 10^{-5} \mathrm{M} \mathrm{CoL}_{2}$ for $10 \mathrm{~min}$ at room temperature and then rinsed with ultrapure water to remove the extra $\mathrm{CoL}_{2}$.

Electrochemical detection: The electrochemical investigation of hybridization was carried out by differential pulse voltammetry (DPV) measurements in $0.2 \mathrm{M}$ PBS buffer ( $\mathrm{pH}$ 6.0 ), with potential scan from $-0.1 \mathrm{~V}$ to $0.6 \mathrm{~V}$. The peak related to the oxidation of $\mathrm{CoL}_{2}$ at approximately $0.31 \mathrm{~V}$ was characterized as the electrochemical detection signal.

\section{RESULTS AND DISCUSSION}

Electrochemical behaviors of $\mathrm{CoL}_{2}$ in presence of dsDNA at bare GCE: Electrochemical behaviors of $\mathrm{CoL}_{2}$ and its interaction with double-stranded salmon sperm DNA (dsDNA) were investigated with GCE at $25{ }^{\circ} \mathrm{C}$. The cyclic voltammograms were obtained at a concentration of $5.52 \times$ $10^{-5} \mathrm{M} \mathrm{CoL}_{2}$ for bare GCE in a $0.2 \mathrm{M} \mathrm{pH}$ 6.0 PBS buffer without dsDNA or containing $8.26 \times 10^{-5} \mathrm{M}$ dsDNA. It was observed that there were a couple of non-reversible redox peaks for $\mathrm{CoL}_{2}$. The cathodic peak potential $\left(\mathrm{E}_{\mathrm{pc}}\right)$ and the anodic peak potential $\left(\mathrm{E}_{\mathrm{pa}}\right)$ were $0.238 \mathrm{~V}$ and $0.310 \mathrm{~V}$ respectively. The peak current decreased and its formal potentials shifted positively with the addition of dsDNA in PBS buffer, suggesting that an interaction between dsDNA and $\mathrm{CoL}_{2}$ took place.

Bard et $a l .{ }^{27}$ had reported the discrimination of binding modes between small molecules and DNA. If formal potential $\left(\mathrm{E}^{\mathrm{o}}\right)$ shifted to more negative value, the interaction mode was electrostatic binding. On the contrary, if $\mathrm{E}^{\mathrm{o} \prime}$ shifted to more positive value, the interaction mode was intercalative binding. Therefore, in our studied system the interaction between $\mathrm{CoL}_{2}$ and DNA can be attributed to the intercalative binding. When the concentration of dsDNA was fixed, the cathodic peak current $\left(\mathrm{I}_{\mathrm{pc}}\right)$ decreased linearly with the increase of concentration of $\mathrm{CoL}_{2}$ (plotted as $\log \left[\Delta \mathrm{I}_{\mathrm{pa}} /\left(\Delta \mathrm{I}_{\mathrm{pa} \cdot \max }-\Delta \mathrm{I}_{\mathrm{pa}}\right)\right]$ to $\log \left\{\left[\mathrm{CoL}_{2}\right] /\right.$ $\mathrm{M}\}$ in Fig. 2. The binding constant between $\mathrm{CoL}_{2}$ and dsDNA was calculated to be $3.59 \times 10^{9} \mathrm{~L}^{2} \mathrm{~mol}^{-2}$ with a correlation coefficient of 0.9887 .

Electrochemical characteristics of oligonucleotides/ MWCNTs-COOH/GCE: Electrochemical characteristics of oligonucleotides/MWCNTs-COOH/GCE scan from $-0.4 \mathrm{~V}$ to $+0.6 \mathrm{~V}$ was shown in Fig. 3. Curve a, b and c were the electrochemical response of bare GCE, MWCNTs-COOH/GCE and

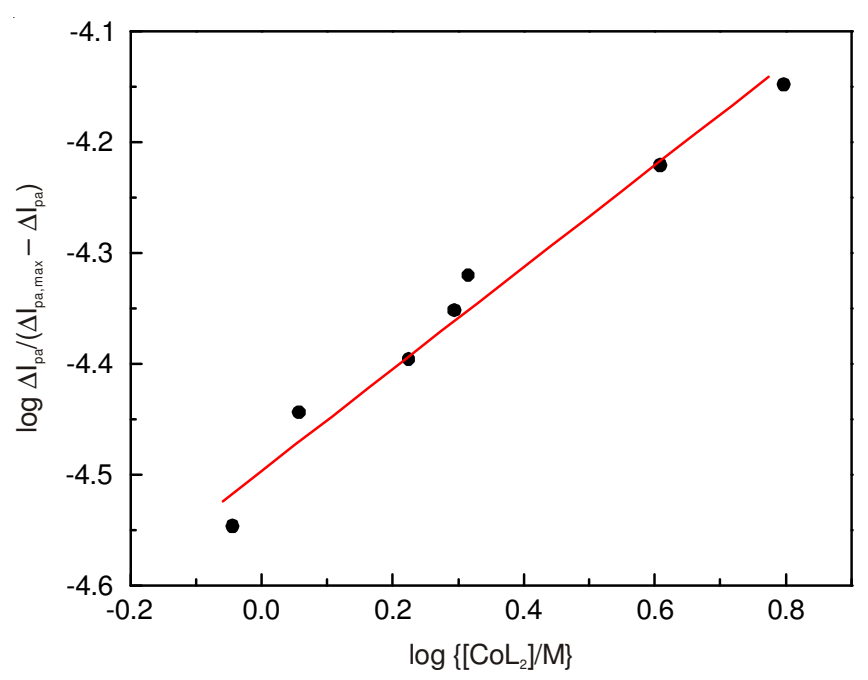

Fig. 2 Dependence of $\log \Delta \mathrm{I}_{\mathrm{pa}} /\left(\Delta \mathrm{I}_{\mathrm{pa}}, \max -\Delta \mathrm{I}_{\mathrm{pa}}\right)$ on $\log \left[\mathrm{CoL}_{2}\right]$

oligonucleotides/MWCNTs-COOH/GCE in 0.1 M PBS (pH 7.0), respectively. As can be seen, after MWCNTs-COOH was deposited on the electrode, a pair of stable redox waves appeared with the cathodic peak potential of $-0.05 \mathrm{~V}$ and the anodic peak potential of $0.01 \mathrm{~V}$, which was related to the redox of carboxylic group of MWCNTs-COOH. Compared with the bare GCE, the background current of the MWCNTs-COOH/ GCE was apparently amplify, showing that modification of the electrode with MWCNTs-COOH could significantly enhance the effective electrode surface area as well as provide an active binding group for oligonucleotides derivation. As a result of oligonucleotides probe coupling to MWCNTs$\mathrm{COOH} / \mathrm{GCE}$, the $\mathrm{CV}$ current of the electrode decreased significantly.

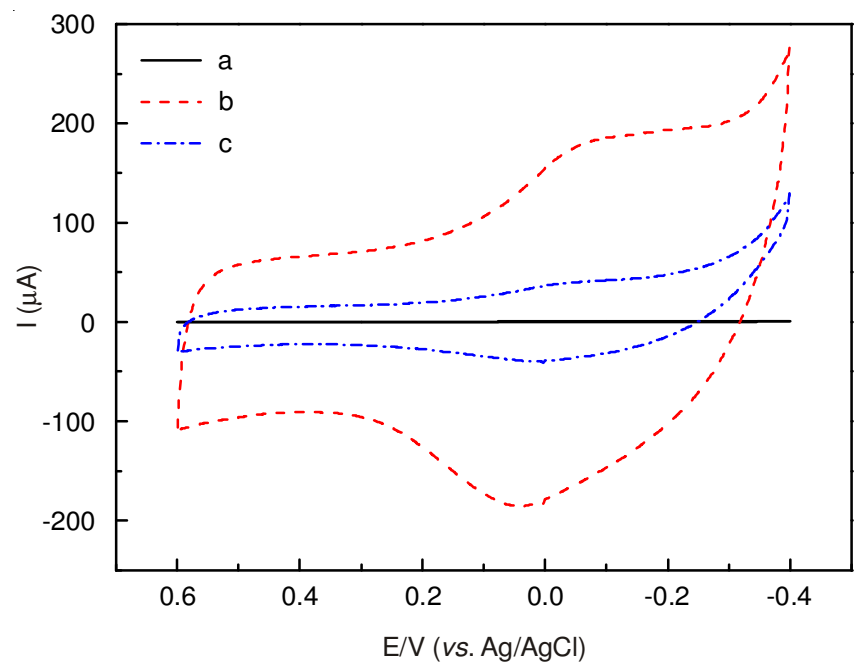

Fig. 3. Cyclic voltammograms of bare GCE (curve a); MWCNTs-COOH/ GCE (curve b) and oligonucleotide/MWCNTs/GCE (curve c) in 0.1 M PBS blank solution ( $\mathrm{pH} 7.0$ )

Selectivity of the prepared electrochemical DNA biosensor: The $\mathrm{CoL}_{2}$ complex was used as DNA hybridization indicator for the detection of a 24-mer oligonucleotide which is specific for colitoxin and the selectivity of this assay was investigated. Fig. 4 showed the DPV curves obtained in $0.2 \mathrm{M}$ tris-HCl buffer (pH 6.0) on MWCNTs-COOH/GCE with 
immobilized probe DNA solely (curve a), further hybridized with complementary DNA (curve e) and non-complementary target DNA (curve b), three-base mismatch target ssDNA (curve c) and single mismatch target ssDNA (curve d) respectively. Each measurement was performed after $\mathrm{CoL}_{2}$ was accumulated. It was found that there was only a small DPV peak response of $\mathrm{CoL}_{2}$ for $\mathrm{S}_{1}$ modified MWCNTs-COOH/GCE (Curve a), indicating that only a negligible $\mathrm{CoL}_{2}$ was bound to $\mathrm{S}_{1}$ on modified MWCNTs-COOH/GCE. A significant increase in the DPV signal was observed after the ssDNA modified MWCNTs$\mathrm{COOH} / \mathrm{GCE}$ was hybridized with the complementary ssDNA, indicating that much more $\mathrm{CoL}_{2}$ molecules were concentrated or bound to dsDNA helices. A good selectivity was thus obtained for the new electrochemical DNA biosensor.

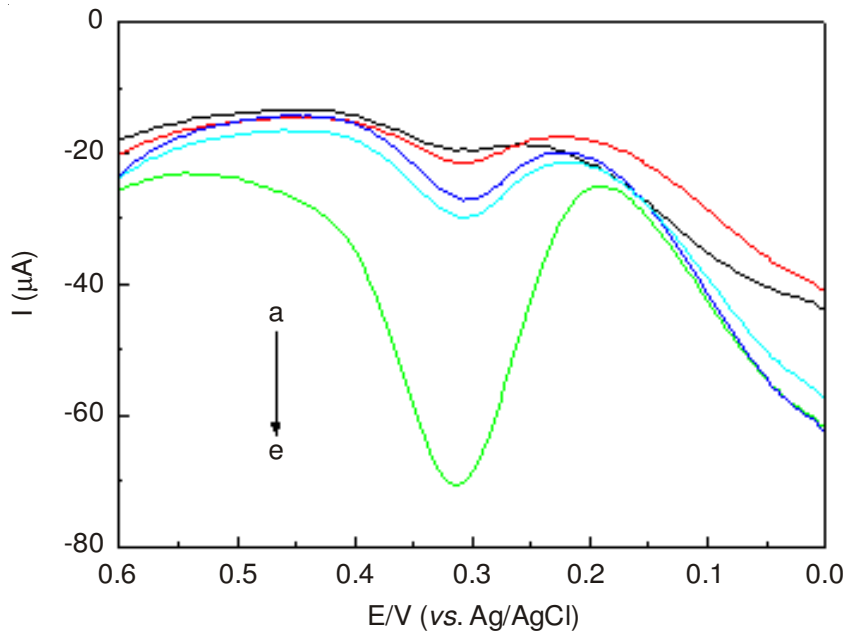

Fig. 4. DPVs curves of $\mathrm{CoL}_{2}$ on the different modified GCEs in $0.20 \mathrm{M}$ tris-HCl buffer solution. (a) $\mathrm{S}_{1} / \mathrm{MWCNTs}-\mathrm{COOH} / \mathrm{GCE}$; (b) $\mathrm{S}_{1}-\mathrm{S}_{5} /$ MWCNTs-COOH/GCE, (c) $\mathrm{S}_{1}-\mathrm{S}_{3} / \mathrm{MWCNTs}-\mathrm{COOH} / \mathrm{GCE}$; (d) $\mathrm{S}_{1}-\mathrm{S}_{4} /$ MWCNTs-COOH/GCE; (e) $\mathrm{S}_{1}-\mathrm{S}_{2} / \mathrm{MWCNTs-COOH/GCE}$, where the concentration of $\mathrm{S}_{2}, \mathrm{~S}_{3}, \mathrm{~S}_{4}, \mathrm{~S}_{5}$ was $36.2 \mathrm{nM}$ respectively

Quantitative analysis of target ssDNA: The sensitivity of the prepared DNA electrochemical sensor was investigated by varying the concentration of target ssDNA, which was complementary to the probe ssDNA immobilized on MWCNTs-

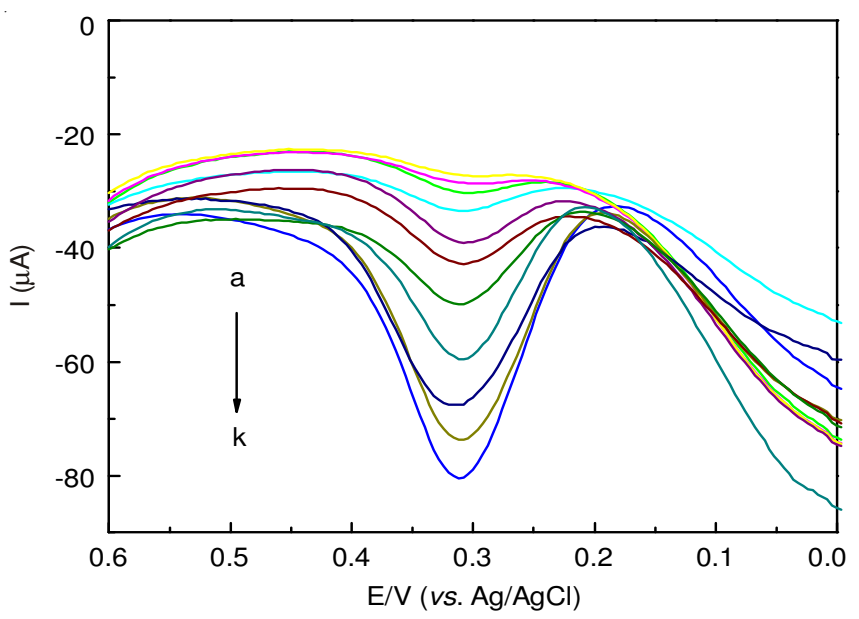

Fig. 5. DPV curves of different $S_{2}$ concentrations, (a) 0 ; (b) $2.00 \times 10^{-9}$ $\mathrm{mol} \mathrm{L}{ }^{-1}$; (c) $4.00 \times 10^{-9} \mathrm{~mol} \mathrm{~L}^{-1}$; (d) $6.00 \times 10^{-9} \mathrm{~mol} \mathrm{~L}^{-1}$; (e) $8.00 \times$ $10^{-9} \mathrm{~mol} \mathrm{~L}^{-1}$; (f) $1.00 \times 10^{-8} \mathrm{~mol} \mathrm{~L}^{-1}$; (g) $2.00 \times 10^{-8} \mathrm{~mol} \mathrm{~L}^{-1}$; (h) 3.00 $\times 10^{-8} \mathrm{~mol} \mathrm{~L}^{-1}$; (i) $4.00 \times 10^{-8} \mathrm{~mol} \mathrm{~L}^{-1}$; (j) $5.00 \times 10^{-8} \mathrm{~mol} \mathrm{~L}^{-1}$;

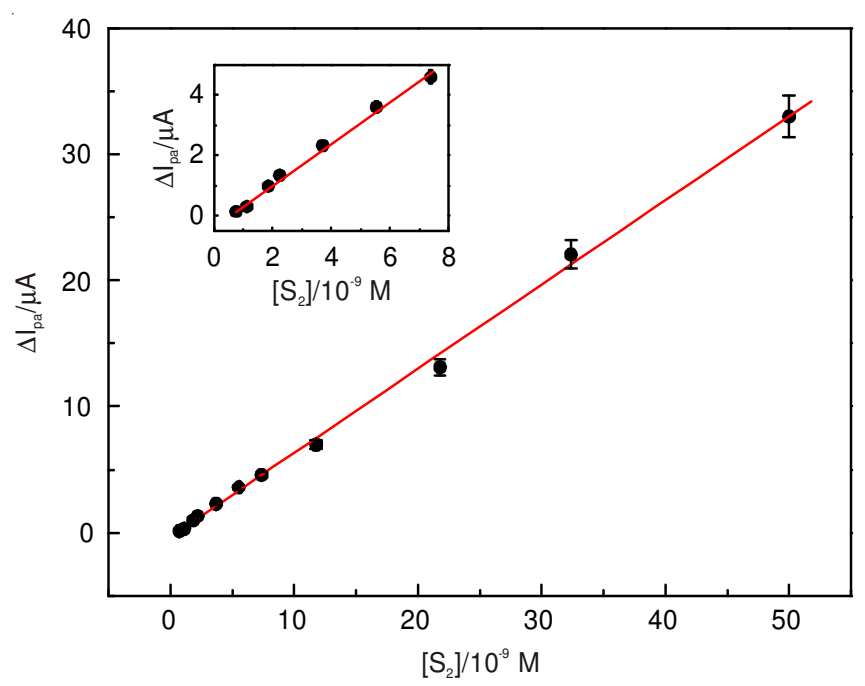

Fig. 6. Relation curve obtained with different amounts complementary target DNA for hybridization

COOH/GCE. As shown in Fig. 5, the differentanodic peak currents obtained in DPV measurement increases with the increasing concentration of $\mathrm{S}_{2}$. The value of peak current difference is linear with the concentration of target ssDNA ranging from $2.00 \times 10^{-9} \mathrm{M}$ to $5.00 \times 10^{-8} \mathrm{M}$ (Fig. 6). The regression equation was $\Delta \mathrm{I}_{\mathrm{pa}}=\left\{6.694\left(\left[\mathrm{~S}_{2}\right] / \mathrm{nM}\right)-0.3645\right\} \times 10^{-7} \mathrm{~A}$ and the correlation coefficient was 0.9989 . Thus, a detection limit of $8.2 \times 10^{-11} \mathrm{M}$ of the target DNA could be estimated using $3 \mathrm{~s}$ (where $\mathrm{s}$ is the standard deviation of the blank solution, $\mathrm{n}=7)$.

\section{Conclusion}

Interaction between $\mathrm{CoL}_{2}$ and double-stranded salmon sperm DNA was studied by using cyclic voltammetry. Results showed that $\mathrm{CoL}_{2}$ could intercalate into the base pairs of the dsDNA. Functionalized multiwall carbon nanotubes (MWCNTs$\mathrm{COOH}$ ) were used for covalent immobilization of ssDNA probe and for the enhancement of sensitivity of sequencespecific ssDNA detection. With $\mathrm{CoL}_{2}$ as a novel electroactive indicator, ssDNA fragment could be selectively detected on the new electrochemical DNA biosensor with a detection limit of $8.2 \times 10^{-11} \mathrm{M}$ and a linear range from $2 \times 10^{-9} \mathrm{M}$ to $5 \times 10^{-8} \mathrm{M}$.

\section{ACKNOWLEDGEMENTS}

This work was supported by the National Natural Science Foundation of China (No. 21075073), the Shandong Province Natural Science Foundation of China (No. ZR2010BZ006) .

\section{REFERENCES}

1. J. Wang, Anal. Chim. Acta, 469, 63 (2002).

2. B. Kuswandi, S. Tombelli, G. Marazza and M. Mascini, Chimia, 59, 236 (2005).

3. F. Davis, M.A. Hughes, A.R. Cossins and S.P.J. Higson, Anal. Chem., 79, 1153 (2007).

4. E.L.S. Wong and J.J. Gooding, Anal. Chem., 78, 2138 (2006).

5. A. Sassolas, B.D. Leca-bouvier and L.J. Blum, Chem. Rev., 108, 109 (2008).

6. G.A. Rivas, M.D. Rubianes, M.C. Rodriguez, N.F. Ferreyra, G.L. Luque, M.L. Pedano, S.A. Miscoria and C. Parrado, Talanta, 74, 291 (2007).

7. A. Erdem, P. Papakonstantinou and H. Murphy, Anal. Chem., 78, 6656 (2006). 
8. J. Kong, N.R. Franklin, C. Zhou, M.G. Chapline, S. Peng, K. Cho, H. Dai, S. Peng and K.J. Cho, Science, 287, 622 (2000).

9. P.G. Collins, K. Bradley, M. Ishigami and A. Zettl, Science, 287, 1801 (2000).

10. J.P. Kim, B.Y. Lee, S. Hong and S.J. Sim, Anal. Biochem., 381, 193 (2008),

11. X.H. Kang, Z.B. Mai, X.Y. Zou, P.X. Cai and J.Y. Mo, Anal. Biochem., 363, 143 (2007).

12. T. Ito, L. Sun, R.R. Henriquez and R.M. Crooks, Acc. Chem. Res., 37, 937 (2004).

13. C.R. Martin, G. Che, B.B. Lakshmi and E.R. Fisher, Nature, 393, 346 (1998).

14. C. Dekker, S.J. Tans and A.R.M. Verschueren, Nature, 393, 49 (1998)

15. J.M. Planeix, N. Coustel, B. Coq, V. Brotons, P.S. Kumbhar, R. Dutartre, P. Geneste, P. Bernier and P.M. Ajayan, J. Am. Chem. Soc., 116, 7935 (1994),

16. P. Poncharal, Z.L. Wang, D. Ugarte and W.A. De Heer, Science, $\mathbf{2 8 3}$, 1513 (1999).

17. S.V. Wegner, A. Okesli, P. Chen and C. He, J. Am. Chem. Soc., 129, 3474 (2007)
18. M.R. Gore, V.A. Szalai, P.A. Ropp, I.V. Yang, J.S. Silverman and H.H. Thorp, Anal. Chem., 75, 6586 (2003).

19. Z.W. Zhu, C. Li and N.Q. Li, Microchem. J., 71, 57 (2002).

20. K. Jiao, Q.J. Li, W. Sun and Z.J. Wang, Electroanalysis, 17, 997 (2005).

21. V. Sivaramakrishnan, P.N.M. Shilpa, V.R.P. Kumar and S.N. Devaraj, Chem.-Biol. Interact., 171, 79 (2008).

22. T.W. Wu, K.P. Fung, J. Wu, C.C. Yang, J. Lo and R.D. Weisel, Life Sci., 58, 17 (1995).

23. S.H. Fang, Y.C. Hou, W.C. Chang, S.L. Hsiu, P.D. Lee Chao and B.L. Chiang, Life Sci., 74, 743 (2003).

24. F. Wang, Y. Xu, J. Zhao and S. Hu, Bioelectrochem., 70, 356 (2007).

25. J.W. Kang, Zh.F. Li and X.Q. Lu, J. Pharm. Biomed. Anal., 40, 1166 (2006).

26. Q. Zhang, L.F. Wang, X. Liu, S.B. Li and F.Y. He, Transition Met. Chem., 21, 23 (1996)

27. M.T. Carter, M. Rodriguez and A.J. Bard, J. Am. Chem. Soc., 111, 8901 (1989). 